\title{
Pricing Benchmark of Empirical Research for Commercial Real Estate Development Project
}

\author{
Yan Kun \\ School of Management, Xi'an University of Architecture and technology, P.R.China \\ 35328770@qq.com
}

\begin{abstract}
Rent of shops is inversely proportional to the distance from the central business district, and is proportional to the quality of the shop itself. This article take a shopping mall project case which is developed by the estate company in Xing Ping District, Xian Yang City as the example, described the basic method of setting the price in commercial real estate development project.
\end{abstract}

Keywords-The core business district, Rent of shops, Price benchmark

\section{Introduction}

Real estate investment is the investment behavior that you put some money into the real estate activities and in the future expecting greater benefit. Because the future compensation has not yet occurred and there is greater uncertainty, the real estate investment could either bring huge benefits, or accompanied by great risk. So to reduce the economic risk of the project, we must contact the actual situation of urban development, by studying urban planning, urban development, the public life of the status quo and the real estate market demand for comprehensive analysis, and follow the laws of the market organization and implementation.

\section{Background and Basic Methods}

Xian Yang City is the third largest city in Shaanxi province, located in the Guan Zhong Plain. The total population is 5.35 million. It is a national historical and cultural city and becomes an emerging industrial city in recent years. A shopping mall commercial building was constructed by Yu Long Real Estate Development Company in Xing Ping District in 2009, before this, the company's market research department predicts the price of the commercial building through market research. In Xing ping District, A shopping mall and B are two very large wholesale business center, A shopping mall construction area is 25,000 square meters and an annual turnover of more than 90 million Yuan, B Wholesale Market covers an area of 300 acres annual turnover of one billion Yuan or more. A shopping mall and B together form the wholesale market area of the core business in Xing Ping District.

In general, the closer shops shopping center, the higher the rent. The higher the quality of its own shops, the rent should be higher. Firm surveyed 29 of the lot near the shops, they were obtained from the distance between the two centers and their own rent, through the company's technical staff based on the quality of construction and fitting of these shops, these shops were quality scoring. Based on these data do econometric analysis, the regression equation, using the regression equation to get the rent of the project, using the present value of annuity factor, has been the benchmark price of the project.

\section{Investigation and Analysis of the Data Model}

According to our marketing department staff survey of specific data (data in Table 1), regression analysis is as follows:

We let $\mathrm{r}$ equal to the rent, $\mathrm{q}$ is equal to the quality scoring, $\mathrm{d}_{\mathrm{A}}$ is equal to the distance from A shopping mall to the shops, $\mathrm{d}_{\mathrm{B}}$ is equal to the distance from wholesale shops to $B$. The quality of rental shops and shops is certainly a positive correlation, we do retail and rental shops in the quality $\mathrm{q}$ and $r$ regression analysis, we get:

$$
r=-0.98132+0.689011 q
$$

(Determination Coefficient $\mathrm{R}_{2}{ }_{2}=0.686762$, Regression Sum of Square $\mathrm{ESS}_{23}=19.15644$, Residual Sum of Squares $\mathrm{RSS}_{23}=8.737419$ )

And then introduce a new variable $\mathrm{d}_{\mathrm{B}}$ that the distance to $\mathrm{B}$ wholesale market, the sample regression equation is:

$$
r=-0.86138-0.00012 d_{B}+0.683277 q
$$

(Determination Coefficient $\mathrm{R}_{2}{ }_{2}=0.689936$, Regression Sum of Square $\mathrm{ESS}_{23}=19.24497$, Residual Sum of Squares $\mathrm{RSS}_{23}=8.648883$ )

Tab. 1 Shops Rent Statistics

\begin{tabular}{|c|c|c|c|c|}
\hline Shops' Name & $\begin{array}{c}\text { The Distance to A } \\
(\mathrm{m})\end{array}$ & $\begin{array}{c}\text { The Distance to B } \\
(\mathrm{m})\end{array}$ & Quality Score & Rent $\left(\right.$ Yuan $\left./ \mathrm{m}^{2} \cdot \mathrm{day}\right)$ \\
\hline Shoe Store & 285 & 805 & 6.3 & 2.67 \\
\hline Clothing Shop & 1345 & 1040 & 5 & 1.5 \\
\hline Food Stores & 945 & 820 & 6 & 2.67 \\
\hline Supply Stores & 360 & 940 & 4.5 & 0.93 \\
\hline Flower Shop & 1225 & 650 & 8.5 & 3.33 \\
\hline E-Commerce & 470 & & & \\
\hline
\end{tabular}




\begin{tabular}{|c|c|c|c|c|}
\hline Clothing Store A & 365 & 875 & 7.5 & 4 \\
\hline Station Electronic City & 250 & 1360 & 5.7 & 2.7 \\
\hline Gift Shop & 735 & 430 & 5 & 0.83 \\
\hline Hot Pot & 1340 & 610 & 4 & 2.97 \\
\hline Clothing Store B & 815 & 350 & 6.5 & 3.5 \\
\hline Clothing Store C & 350 & 890 & 6.5 & 2.74 \\
\hline Sweater Shop & 260 & 860 & 5.5 & 1.23 \\
\hline Clothing Store D & 760 & 360 & 6.5 & 3.5 \\
\hline Sock Shop & 350 & 890 & & \\
\hline
\end{tabular}

These data come from the market research of 29 shops around A and B

Since the introduction of more explanatory variables, $\mathrm{R}_{2}$ greater, RSS is smaller. In order to test whether the new introduction $\mathrm{d}_{\mathrm{B}}$ is a significant explanatory variable, we cannot simply look at whether $R_{2}$ is increased or RSS is reduced. We should look at that whether a significant increase in the degree of interpretation of $r$ after the introduction of $d_{B}$. We test using Analysis of variance after the introduction of $d_{B}$, in the total variation, the variation explained by the increase in part is:

$\mathrm{ESS}_{23}-\mathrm{ESS}_{2}=19.24497-19.15644=0.08853$, the increase of degree of freedom is 1 . Use the $F$ statistic $F=\frac{0.08853 / 1}{8.648883 /(29-3)}=0.266136$

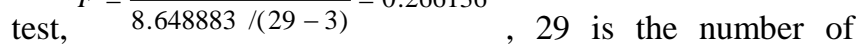
sample. Threshold look-up table available $\quad F_{0.05}(1,26)=4.22 \quad, \quad$ because $F=0.266136<F_{0.05}(1,26)=4.22$, so newly introduced explanatory $\mathrm{d}_{\mathrm{B}}$ variable was not significant, cannot be introduced.

We do not use $d_{B}$, introducing a new variables $d_{A}$ which is the distance to A shopping mall shops, get the sample regression equation is:

$r=-0.644917-0.000094 d_{A}+0.497395 q$

(Determination Coefficient $\mathrm{R}_{2}{ }_{2}=0.829585$, Regression Sum of Square $\mathrm{ESS}_{23}=23.14033$, Residual Sum of Squares $\mathrm{RSS}_{23}=4.753227$ )

Also be given $F=\frac{(23.14033-19.15644) / 1}{4.753527 /(29-3)}=21.79037>F_{0.05}(1,26)=4.22$ .Ther efore, the introduction of new explanatory variables $d_{A}$ are significant. Since the introduction of $\mathrm{d}_{\mathrm{A}}$, compared to equation (1), from 0.686762 to 0.829585 , down from 8.737419 to 4.753527 , improvement is obvious.

Finally, our sample regression equation is:

$$
\begin{gathered}
r=0.644917-0.00094 d_{A}+0.497395 q, \\
R^{2}=0.829585
\end{gathered}
$$

\section{Conclusions}

The distance to A shopping mall is $\mathrm{d}_{\mathrm{A}=} 800 \mathrm{~m}$, the quality score $\mathrm{q}=7$ points, into the above regression equation

$r=0.644917-0.00094 \times 800+0.497395 \times 7=3.374682\left(\right.$ Yuan $/ \mathrm{m}^{2} \bullet$ day $)$

.Then the annual rent is $3.37462 \times 365=1231.7589$ ( Yuan $/ \mathrm{m}^{2}$ • year $)$. Investment in the company's external publicity of the commercial rate of return of 9 percent floor, if you take the 20-year payback period, the price is:

$1231.7589 \times$ PVIFA $(9 \%, 20)=1231.7589 \times 9.129=11244.73\left(\right.$ Yuan $\left./ \mathrm{m}^{2}\right)$

For insurance purposes, we recommend taking the price of the benchmark to calculate the price of $85 \%$, and we also recommend that the commercial building housing along the street price of the benchmark is $11244.73 \times 0.85=9558.021\left(\mathrm{Yuan} / \mathrm{m}^{2}\right)$, the other floors may refer to the appropriate price of a sale. Later, the project house along the street level of the actual price of about 9400-11000 per hour, and we had basically the same pricing forecasts, indicating that our pricing is feasible, should be promoted.

\section{References}

[1] Lianghu Mao, On the project development of technical and economic evaluation[J],JiangSu: Jiangsu Institute of Petrochemical Technology,2002(4):49-50.

[2] Anbang Qi,Dashuang Dai, Feasibility study and evaluation [M],Beijing: Machinery Industry Press ,2004:201-412.

[3] Kevin Yu,Thomas Froese \& Francois Grobler. A development framework for data models for computer-integrated facilities management[J]. Automation in Construction, 2009: 64-65

[4] Youli Wang,Ministry of Construction. Real estate development project economic evaluation methods [M]. Beijing: China Planning Press ,2000:80-81 